\title{
Management of Coriander Wilt (Fusarium oxysporium) through Cultural Practices as Organic Amendments and Date of Sowing
}

\author{
Mukesh Kumar Jat*, R.R. Ahir, Sanju Choudhary and G.L. Kakaraliya \\ Department of plant pathology, SKN College of Agriculture, SKN Agriculture University, \\ Jobner, Jaipur (Raj.) 303329, India \\ *Corresponding author
}

\section{A B S T R A C T}

\begin{tabular}{|l|}
\hline K e y w o r d s \\
Coriander, \\
$\begin{array}{l}\text { Fusarium } \\
\text { oxysporum, } \\
\text { Plant extracts, } \\
\text { Host resistance. }\end{array}$ \\
\hline Article Info \\
\hline $\begin{array}{l}\text { Accepted: } \\
\text { 14 July 2017 } \\
\text { Available Online: } \\
\text { 10 September } 2017\end{array}$ \\
\hline
\end{tabular}

Keywords

Coriander,

Fusarium

oxysporum

Plant extracts,

Article Info

Accepted:

Available Online:
The trials were conducted with various organic amendments i.e. Neem oil cake, Groundnut cake, Castor cake, Mustard cake \& Poultry manure and four dates of sowing i.e. $30^{\text {th }}$ October, $10^{\text {th }}, 20^{\text {th }}$ and $30^{\text {th }}$ November. Analysis of pooled data showed that crop planted on $30^{\text {th }}$ November showed minimum disease incidence and crop sown on $30^{\text {th }}$ October showed maximum disease incidence and minimum seed yield. Data indicated that crop planted on $30^{\text {th }}$ November gave highest yield $639.25 \mathrm{~kg} / \mathrm{ha}$. Studies on the relative efficacy of organic cakes in under field conditions showed Neem oil cake was found most effective followed by Mustard oil cake. Poultry manure was found least effective among these organic amendments. Neem oil cake recorded 21.45 per cent disease incidence with 52.25 per cent disease control and $790.50 \mathrm{~kg} / \mathrm{ha}$ seed yield by increasing 119.02 per cent seed yield.

\section{Introduction}

Coriander occupied prime place amongst the seed spices grown in northern India particularly in Rajasthan. In India, it occupies 447 thousand hectares area with annual production 314 thousand tonnes. The average productivity of coriander seed is $702 \mathrm{~kg} / \mathrm{ha}$ (Anonymous, 2014-15). Disease can also be a serious problem in coriander crop. The important diseases are wilt caused by Fusarium oxysporum (Narula and Joshi, 1963; Srivastava, 1972), the wilt disease causes up to 60 per cent yield loss in coriander (Manoranjitham et al., 2003). The seed yield losses caused by Fusarium wilt ranges from 5 to 60 per cent in Rajasthan and
15 to 25 per cent in Gujarat (Prasad and Patel, 1963). Whereas, Mathur and Prasad (1964) reported an average seed yield loss of 20 per cent in Rajasthan due to Fusarium wilt with disease incidence of 70 to 80 per cent.

\section{Materials and Methods}

\section{Effect of organic amendments under field conditions}

Field experiments were conducted during winter season of 2013-14 and 2014-15 at Agronomy farm, SKN College of Agriculture, Jobner in Randomized Block Design (RBD) 
with six treatments including control with four replications in $2 \times 2 \mathrm{~m}^{2}$ plot size. Usual agronomical practices were followed in preparation of the field. In both the years, the experiments were sown in the third week of November.

Soil was amended with five organic amendments were made 2 week prior to sowing @ 200 g/plot $\left(2 \times 2 \quad \mathrm{M}^{2}\right)$. A light irrigation was applied after amendment. Plots without amendment served as check. Highly susceptible coriander variety $\mathrm{RCr}-435$ was sown. The organic amendments used are mentioned below:

Per cent disease incidence was calculated by using formula given below. At harvesting, seed yield per plot was also recorded and calculated in $\mathrm{kg} / \mathrm{ha}$.

Per cent

Number of infected plants

Disease incidence $=\longrightarrow \times 100$

Total number of plants observed

\section{Effect of date of sowing}

Incidence of wilt disease was observed on coriander plants sown at four different dates. Sowing was done from 30th October to 30th November at an interval of ten days at the experimental farm of S.K.N. College of Agriculture, Jobner during both seasons 201314 \& 2014-15. Wilt is known to occur in severe form under natural field conditions in this area. The experiment was laid out in RBD with four replications. In each replication, standard plant populations were maintained in plot of $2 \times 2 \mathrm{~m}^{2}$. The sowing dates were as follows:

30 October

10 November

20 November

30 November
The crop was observed regularly for wilt incidence. Disease incidence was recorded at 45 DAS by examining the plants randomly selected in each plot starting from the initiation of the disease. At harvesting, seed yield per plot was also recorded and calculated in $\mathrm{kg} / \mathrm{ha}$.

\section{Results and Discussion}

\section{In vivo effect of organic amendment against Fusarium oxysporum f. sp. corianderii}

It is evident from the data that all the organic amendment tested reduced wilt incidence of coriander significantly over check. Neem oil cake was found significantly superior over all other treatments result a maximum disease control $(58.95 \%)$ followed by Groundnut cake (54.05\%), Castor cake (50.86\%) and Mustard cake $(44.15 \%)$. Poultry manure was least effective in reducing wilt incidence $(41.15 \%)$ (Table 1). Two year pooled data of seed yield indicated that highest $790.50 \mathrm{~kg} / \mathrm{ha}$ seed yield was recorded in Neem cake with increasing 119.02 per cent seed yield followed by Groundnut cake $(712.15 \mathrm{~kg} / \mathrm{ha})$ seed yield with increasing 97.32 per cent over control.

In vivo condition all the amendment, cakes namely Neem cake, Groundnut cake, Castor cake, Mustard cake and Poultry manure were tested against Fusarium oxysporum f.sp. corianderii.

Among the oil cakes, Neem cake was found most effective to control the disease up to 58.95 per cent under field condition with maximum $790.50 \mathrm{~kg} / \mathrm{ha}$ seed yield, followed by Groundnut cake $(54.05 \%)$ under field condition with $712.15 \mathrm{~kg} / \mathrm{ha}$ seed yield. Poultry manure control the disease up to 41.15 per cent under field condition with $398.89 \mathrm{~kg} / \mathrm{ha}$ seed yield were least effective in reducing wilt incidence. 
Table.1 Effect of soil treatment with various organic amendment on wilt disease incidence and Yield of coriander under field condition

\begin{tabular}{|c|c|c|c|c|c|c|c|c|c|}
\hline \multirow[t]{2}{*}{ Organic amendment } & \multirow{2}{*}{$\begin{array}{c}\text { Dose } \\
\left(\mathrm{q} \text { ha }^{-1}\right)\end{array}$} & \multicolumn{3}{|c|}{ Per cent disease incidence* } & \multirow{2}{*}{$\begin{array}{l}\text { Decrease in PDI over } \\
\text { control (per cent) }\end{array}$} & \multicolumn{3}{|c|}{ Yield (kg /ha)* } & \multirow{2}{*}{$\begin{array}{l}\text { Increase in yield over } \\
\text { control (per cent) }\end{array}$} \\
\hline & & 2013-14 & 2014-15 & Pooled & & 2013-14 & 2014-15 & Pooled & \\
\hline Groundnut cake & 5 & $\begin{array}{c}24.40 \\
(29.60)\end{array}$ & $\begin{array}{c}23.62 \\
(29.08)\end{array}$ & $\begin{array}{c}24.01 \\
(29.34)\end{array}$ & 54.05 & 694.00 & 730.30 & 712.15 & 97.32 \\
\hline Neem cake & 5 & $\begin{array}{l}22.71 \\
(28.46)\end{array}$ & $\begin{array}{l}20.19 \\
(26.70)\end{array}$ & $\begin{array}{l}21.45 \\
(27.59)\end{array}$ & 58.95 & 761.30 & 819.70 & 790.50 & 119.02 \\
\hline Castor cake & 5 & $\begin{array}{l}26.90 \\
(31.24)\end{array}$ & $\begin{array}{l}24.45 \\
(29.63)\end{array}$ & $\begin{array}{l}25.68 \\
(30.44)\end{array}$ & 50.86 & 664.15 & 692.80 & 678.48 & 87.98 \\
\hline Mustard cake & 5 & $\begin{array}{l}29.83 \\
(33.10)\end{array}$ & $\begin{array}{c}28.54 \\
(32.29)\end{array}$ & $\begin{array}{l}29.19 \\
(32.70)\end{array}$ & 44.14 & 590.51 & 630.30 & 610.41 & 69.12 \\
\hline Poultry manure & 25 & $\begin{array}{l}32.40 \\
(34.70)\end{array}$ & $\begin{array}{l}29.10 \\
(32.65)\end{array}$ & $\begin{array}{c}30.75 \\
(33.68)\end{array}$ & 41.15 & 509.28 & 537.50 & 523.39 & 45.02 \\
\hline Control & - & $\begin{array}{r}53.15 \\
(46.81) \\
\end{array}$ & $\begin{array}{r}51.35 \\
(45.77) \\
\end{array}$ & $\begin{array}{r}52.25 \\
(46.29) \\
\end{array}$ & & 343.64 & 378.20 & 360.92 & \\
\hline $\mathrm{SEm} \pm$ & & 0.91 & 1.04 & 1.00 & & 21.17 & 23.42 & 19.57 & \\
\hline $\mathrm{CD}(\mathrm{p}=0.05)$ & & 2.75 & 3.12 & 3.01 & & 63.80 & 70.57 & 58.99 & \\
\hline $\mathrm{CV}(\%)$ & & 5.77 & 7.01 & 6.53 & & 7.13 & 7.42 & 6.39 & \\
\hline
\end{tabular}

* Average of four replications

Figures in parenthesis are angular transformed values

Table.2 Effect of dates of sowing on wilt disease incidence and seed yield of coriander

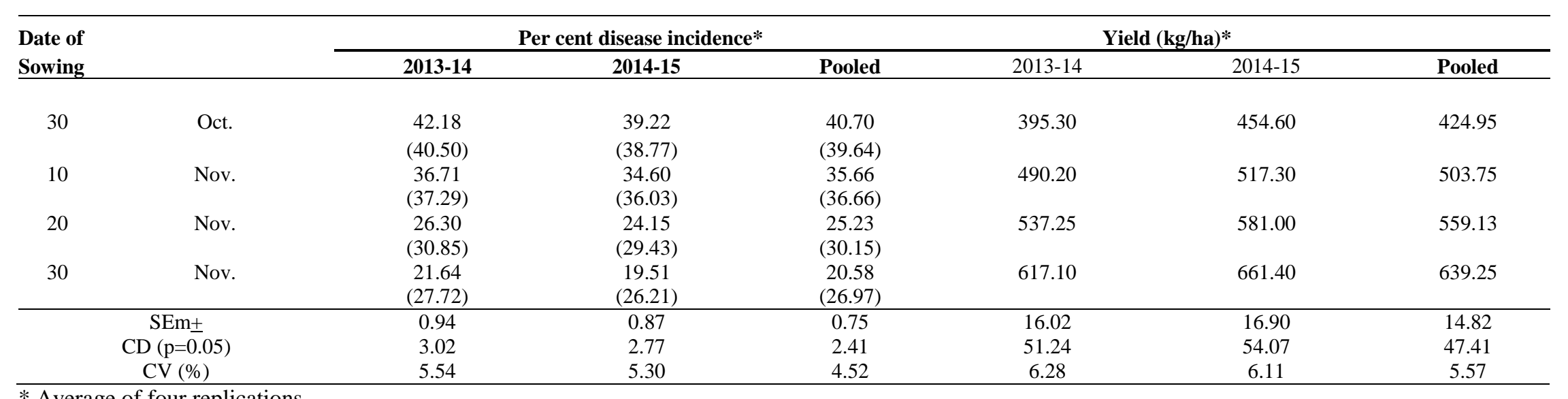

* Average of four replications

Figures in parenthesis are angular transformed value 


\section{Effect of organic amendments under field conditions}

\begin{tabular}{|c|c|c|}
\hline S. No. & Organic amendment & Dose (q ha $\left.\mathbf{~}^{-1}\right)$ \\
\hline 1 & Groundnut cake & 5 \\
\hline 2 & Neem cake & 5 \\
\hline 3 & Castor cake & 5 \\
\hline 4 & Mustard cake & 25 \\
\hline 5 & Poultry manure & 5 \\
\hline
\end{tabular}

Our observations are in conformity to Kimaru, et al., (2004), who conducted both in the laboratory and greenhouse conditions to investigate the effects of Neem Kernel cake powder (NKCP) on growth, sporulation and pathogenicity of tomato wilt caused by Fusarium oxysporum f. sp. lycopersici and in both the condition Neem cake was found significantly effective. Yelmame et al., (2010), were tested the extracts of different organics of Neem cake, Mustard cake, FYM, Groundnut cake, Poultry manure, Press mud, Castor cake and coconut cake against Fusarium solani caused wilt of chilli in in vitro. Minimum growth of pathogen was recorded in the extracts of Neem cake showing excellent inhibitory effect $(59.8 \%)$ followed by Mustard cake (52.61\%). Nikam et al., (2007) tested various oilseed cakes viz., Groundnut cake, Cotton seed cake, Neem cake and Castor seed cake. Amongst four oil cakes tested Groundnut cake is proved to be effective against $F$. oxysporum f. sp. ciceri followed by Neem cake and Castor cake in checking per cent wilt incidence by 61.91, 52.39 and 47.67 per cent, respectively as against control.

\section{Effect of sowing dates}

A trial was conducted with four dates of sowing i.e. $30^{\text {th }}$ October, $10^{\text {th }}, 20^{\text {th }}$ and $30^{\text {th }}$ November. The pooled data presented in Table 2 indicated that disease incidence showed a decreasing trend with the delayed sowing, where disease incidence was maximum 40.70 per cent on $30^{\text {th }}$ October sown crop closely followed by 35.66 per cent on $10^{\text {th }}$ November sown crop and 25.53 per cent in $20^{\text {th }}$ November sown crop. Minimum 20.58 per cent disease incidence was observed in $30^{\text {th }}$ November sown crop (Table 2). The pooled analysis of seed yield data indicated that seed yield was lowest $(424.95 \mathrm{~kg} / \mathrm{ha})$ in case of $30^{\text {th }}$ October sown crop followed by $10^{\text {th }}$ November sown crop $(503.75 \mathrm{~kg} / \mathrm{ha})$ However, in spite $30^{\text {th }}$ November sown crop recorded maximum $(639.25 \mathrm{~kg} / \mathrm{ha})$ seed yield. Our results indicated that crop planted on $30^{\text {th }}$ October had highest disease incidence $(40.70 \%)$ and lower seed yield. Crop planted on $30^{\text {th }}$ November had minimum disease incidence (20.58\%). Maximum $661.40 \mathrm{~kg} / \mathrm{ha}$ seed yield was recorded in $30^{\text {th }}$ November sown crop with 20.58 per cent disease incidence. It was suggested that planting date of $30^{\text {th }}$ November better in this agro climatic zone. Our findings are in contradiction with finding of Deepak et al., (2008) as observed incidence of wilt disease of cumin was more on $30^{\text {th }}$ October sown cumin crop was more in comparison to late sown crop. The reason is that in early sown crop ( $10^{\text {th }}$ October $)$, the incidence of disease was more as in January pathogen have more congenial climatic condition.

Gangwar et al., (2009), observed that incidence of wilt disease of chickpea were six sowing dates started from $4^{\text {th }}$ October to $8^{\text {th }}$ November at weekly intervals showed that disease incidence gradually decreased and crop yield gradually increased with postponing the sowing date. 


\section{References}

Anonymous. 2014-15. www.eands.dacnet. net.in/PDF/Agriculture statistics-AtGlance 2014.Pdf.

Deepak. P., Saran, L. and Lal, G. 2008. Control of wilt and blight diseases of cumin through antagonistic fungi under In Vitro and field conditions. Not. Bot. Hort. Agrobot. Cluj 36 (2): 91-96.

Gangwar, R.K., Chaudhary, R.G. and Kumar, K. 2009. Effect of cultural practices and edaphic environment on chickpea wilt caused by Fusarium oxysporum f. sp. Ciceri. Journal of Food Legumes. 22 (4): 273-275.

Kimaru, S.K., Waudo, S.W., Manda, E., Seif, A.A. and Birgen, J.K. 2004. Effect of Neem Kernel Cake Powder (NKCP) on wilt of tomato when used as soil amendment. Journal of Agriculture and Rural Development in the Tropics and Subtropics. Vol.105 (1).

Manoranjitham, S.K., Rabindram, R. and Doraiswamy, S. 2003. Management of seed borne pathogens and wilt disease of coriander. Madras Agricultural Journal 90: 4-6.
Mathur, B.N., and Prasad, N. 1964. Studies on wilt disease of cumin caused by Fusarium oxysporum f. sp. cumini. Indian J. Agri. Sci. 34 (2): 131-137.

Narula S.C., and Joshi P.S. 1963. Fusarium oxysporum Sch. f.sp. coriandrii. Sci. Cult. 29: 206.

Nikam, P.S., Jagtap, J.P. and Sontakke, P.L. 2007. Management of chickpea wilt caused by Fusarium oxysporum f.sp. ciceri. African Journal of Agricultural Research, 2 (12): 692-697.

Prasad, N., and Patel, P.N. 1963. Fusarium wilt of cumin in Gujarat state, Indian Plant Dis. Report. 47 (6): 528-531.

Srivastava, U.S., 1972. Effect of interaction of factors on wilt of coriander caused by Fusarium oxysporum f. sp. Corianderii, Kulkarni, Nikam \& Joshi. Indian $J$. Agric. Sci. 42:618-620.

Yelmame, M.G., Mehta, B.P., Deshmukh, A.J. and Patil, V.A. 2010. Evaluation of some organic extracts in in vitro to control Fusarium solani causing chilli wilt. International Journal of Pharma and Bio Sciences, 1(2): 19-20.

\section{How to cite this article:}

Mukesh Kumar Jat, R.R. Ahir, Sanju Choudhary and G.L. Kakaraliya. 2017. Management of Coriander Wilt (Fusarium oxysporium) through Cultural Practices as Organic Amendments and Date of Sowing. Int.J.Curr.Microbiol.App.Sci. 6(9): 896-900. doi: https://doi.org/10.20546/ijcmas.2017.609.108 